\title{
Evaluation of tomato accessions for quantitative and qualitative traits under agro climatic condition of Peshawar
}

\author{
Nadia Samad ${ }^{1}$, Neelam Ara ${ }^{1}$, Amir Sohail ${ }^{2 *}$, Shahzad Ali ${ }^{3}$, Manzoor $^{3}$, \\ Shah Fahad ${ }^{3}$, Quaid Hussain ${ }^{2}$, Maryam Samad ${ }^{1}$ and Umair Hizar ${ }^{1}$ \\ 1. Department of Horticulture, The University of Agriculture, Peshawar, Khyber Pakhtunkhwa-Pakistan \\ 2. Department of Plant Breeding and Genetics, The University of Agriculture, Peshawar, Khyber Pakhtunkhwa- \\ Pakistan \\ 3. Department of Agronomy, The University of Agriculture, Peshawar, Khyber Pakhtunkhwa-Pakistan. \\ *Corresponding author's email: amirsohail@aup.edu.pk
}

Citation

Nadia Samad, Neelam Ara, Amir Sohail, Shahzad Ali, Manzoor, Shah Fahad, Quaid Hussain, Maryam Samad and Umair Hizar. Evaluation of tomato accessions for quantitative and qualitative traits under agro climatic condition of Peshawar. Pure and Applied Biology. Vol. 6, Issue 4, pp1345-1353. http://dx.doi.org/10.19045/bspab.2017.600145

\begin{tabular}{llll}
\hline \hline Received: 07/07/2017 & Revised: 19/10/2017 & Accepted: 21/10/2017 & Online First: 26/10/2017 \\
\hline \hline
\end{tabular}

\section{Abstract}

The objective of this research was to screen the tomato accessions for quantative and qualitative traits under agro climatic condition of Peshawar. 17 tomato accessions with a tomato commercial cultivar were evaluated in randomized complete block design with three replication at The University of Agriculture Peshawar, during kharif season 2016. Quantative traits studied were juice $\mathrm{pH}$, total soluble solids, days to flowering, plant height, fruits plant $^{-1}$, fruit weight and fruit yield plant ${ }^{-1}$. While qualitative traits comprised plant growth type, canopy size, leaf type, flower inflorance, fruit color, fruit shape and fruit firmness. Highly significant differences were observed among tomato accessions for all the quantative traits studied except juice $\mathrm{pH}$. While qualitative traits showed that maximum accessions had indeterminate growth habit $(88.9 \%)$, Intermediate canopy size (55.6\%), curled leaf type (66.7\%), medium number of flowers inflorescence ${ }^{-1}(55.6 \%)$, red fruit color $(61.1 \%)$, deep globe fruits $(26.7 \%)$ and soft fruit firmness $(83.3 \%)$. Fruit yield plant ${ }^{-}$ ${ }^{1}$ showed significant positive correlation with juice $\mathrm{pH}(\mathrm{r}=0.580 * *)$, TSS $(\mathrm{r}=0.500 * *)$, plant height $\left(\mathrm{r}=0.420^{* *}\right)$, fruits $\operatorname{plant}^{-1}\left(\mathrm{r}=0.410^{* *}\right)$ and fruit weight $(\mathrm{r}=0.920 * *)$ except days to flowering $(\mathrm{r}=-$ $\left.0.310^{* *}\right)$ which showed significant negative correlation with fruit yield plant ${ }^{-1}$. Roma showed highest value of fruit juice $\mathrm{pH}$ (4.1), total soluble solids (6.1), fruit weight (54.2 g) and fruit yield plant $^{-1}$ (688.7 g). Therefor this study suggested that Roma and 31910 could be recommended as commercial cultivars under agro climatic condition of Peshawar and also could be used in future tomato breeding programs.

Keywords: Evaluation; Tomato accessions; Quantative traits; Qualitative traits; Correlation

\section{Introduction}

Tomato (Lycopersicon esculentum) is a selfpollinated fruit berry and the second most important vegetable crop cultivated throughout the world [1]. It belongs to family solanaceae with approximately 90 genera and 3,000-4,000 species, some of which are economically important such as potatoes, eggplants, peppers and tobacco [2, 3]. It originated from Central and South America. 
It is one of the most important crops widely grown in tropical and temperate regions of the world. Tomato have three different types of growth habits namely; determinate, indeterminate and semi determinate [4].

Over the last century, tomato as a major horticultural vegetable crop has attained a tremendous popularity. It can be grown in most places all over the world, like growing in the field, greenhouses and net houses. In Pakistan tomato is grown both as Kharif and Rabi crop on an area of 1689 and 38549 hectares with an average production of 142113 and 423930 tons respectively. The Khyber Pakhtunkhwa (KPK) Province share for Kharif and Rabi crop is 9670 and 3582 hectares with 85754 and 41798 tons production [5].

Tomato is also known as protective food because of its special nutritive values [6]. The tomato fruit is moderately rich in Vitamin A and $\mathrm{C}$ and contains $93.8 \mathrm{~g}$ water, $1.2 \mathrm{~g}$ protein, $4.8 \mathrm{~g}$ carbohydrate, $0.5 \mathrm{mg}$ carotene [7]. Yellow tomatoes have higher vitamin A content than red tomatoes, but red tomatoes contain lycopene, an anti-oxidant that may contribute to protection against carcinogenic substances. Red color of tomato fruits is the result of chlorophyll degradation as well as synthesis of lycopene and other carotenoids [8].

For sustainable genetic improvement of the crop systematic study and characterization of tomato germplasm is of great importance. For improved breeding program, evaluation is vital in order to know the genetic background and the breeding values of the available tomatoes [9]. Yield components and morphological traits have been widely used in the evaluation of tomato crops. Therefore the current study was conducted to know about the genetic variability of quantitative and qualitative traits in tomato germplasm under agro climatic condition of Peshawar and to select the most promising tomato accessions for future breeding programs.

\section{Materials and methods}

The experiment was carried out at The University of Agriculture Peshawar in summer season 2016.17 tomato accessions and a commercial variety were procured from National Agricultural Research Centre (NARC), Islamabad (Table 1). Those seeds were sown in plastic tubes on 17 March, 2016. After a week of seeding those accessions were transplanted to the field using randomized complete block design with three replication. Data were noted on five plants genotype ${ }^{-1}$ for various qualitative and quantitative traits. Qualitative traits were measured according to International Plant Genetic Resources Institute descriptors list for tomato (Table 2) [10]. Quantative traits studied were days to flowering, plant height, fruits plant ${ }^{-1}$, fruit weight, fruit juice $\mathrm{pH}$, Soluble Solids (TSS), fruit yield plant ${ }^{-1}$.

\section{Statistical analysis}

Quantative traits were subjected to Analysis of variance (ANOVA) according to [11]. Genotypes that showed significant differences were subjected to Least Significant Difference (LSD) test at 5\% probability level. Correlation and frequency distribution of qualitative traits were analyzed using statistical package 'STATISTICA-V.8.1.

Table 1. List of 17 Tomato Accessions and a commercial Variety studied in the experiment

\begin{tabular}{|c|c|c|c|c|c|}
\hline S. NO. & Accession \# & S.NO & Accession \# & S.NO & Accession \# \\
\hline 1 & 31910 & 7 & 17882 & 13 & 17884 \\
\hline 2 & 29471 & 8 & 17876 & 14 & 19900 \\
\hline 3 & 17877 & 9 & 17876 & 15 & 19904 \\
\hline 4 & 19903 & 10 & 6237 & 16 & 19293 \\
\hline 5 & 17873 & 11 & 27726 & 17 & 19297 \\
\hline 6 & 29448 & 12 & 19895 & 18 & Roma \\
\hline
\end{tabular}


Table 2. Minimal descriptor list for tomato (IPGRI, 1996)

\begin{tabular}{|c|c|c|c|}
\hline Plant characteristics & Score & Fruit characteristics & Score \\
\hline \multicolumn{2}{|c|}{ Plant growth type } & \multicolumn{2}{|c|}{$\begin{array}{r}\text { Fruit color } \\
\end{array}$} \\
\hline Dwarf & 1 & white & 1 \\
\hline Determinate & 2 & Green & 2 \\
\hline Semi-determinate & 3 & Yellow & 3 \\
\hline Indeterminate & 4 & Gold & 4 \\
\hline \multicolumn{2}{|c|}{ Canopy size } & Orange & 5 \\
\hline Small & 1 & Pink & 6 \\
\hline Indeterminate & 2 & Red & 7 \\
\hline Large & 3 & \multicolumn{2}{|c|}{ Fruit shape } \\
\hline \multicolumn{2}{|l|}{ Leaf type } & Oblate & 1 \\
\hline Rugose & 1 & Deep oblate & 2 \\
\hline Potato leaf & 2 & Globe & 3 \\
\hline Regular & 3 & Deep globe & 4 \\
\hline Curled & 4 & Heart shaped & 5 \\
\hline \multicolumn{2}{|c|}{ Flowers inflorence ${ }^{-1}$} & Cylindrical & 6 \\
\hline Low & 1 & Pyriform & 7 \\
\hline Medium & 2 & \multicolumn{2}{|c|}{ Fruit firmness } \\
\hline High & 3 & Soft & 1 \\
\hline \multicolumn{2}{|c|}{ Type of inflorance } & Medium & 2 \\
\hline Simple & 1 & Hard & 3 \\
\hline Forked & 2 & & \\
\hline Compound & 3 & & \\
\hline
\end{tabular}

\section{Results and discussion Tomato juice $\mathbf{p H}$}

Data regarding total juice $\mathrm{pH}$ is presented in (Table 3). Analysis of variance revealed nonsignificant difference among tomato accessions for juice $\mathrm{pH}$. Maximum value of juice $\mathrm{pH}$ was recorded for Roma (4.3) while minimum juice $\mathrm{pH}$ was noted for accession 29471 (3.9). The present results are in line with Ghasemi et al., Henareh et al. and Olakojo et al. [12-14]. They also reported significant difference for juice $\mathrm{pH}$ in tomato genotypes. The juice $\mathrm{pH}$ was significantly $(\mathrm{P}$ $\leq 0.01$ ) positive correlated with total soluble solids, fruits plant ${ }^{-1}$, fruit weight and fruit yield plant ${ }^{-1}$, while with plant height it was non-significantly positive correlated. However juice $\mathrm{pH}$ had non-significant negative correlation with days to flowering (Table 4). Aoun et al. [15] also found that juice $\mathrm{pH}$ was significantly positive correlated with total soluble solids.
Total soluble solids ( $\left.{ }^{\circ} \mathrm{Brix}\right)$

Statistically analyzed data showed significant differences $(\mathrm{P} \leq 0.01)$ among tomato accessions for total soluble solids. Maximum total soluble solids were recorded for accession 31910 (6) followed by Roma (6), while minimum total soluble solids was recorded for accession 19471 (3.5). These results are strengthened by the findings of Chernet et al. and Parkar and Maleekuu [16, 17]. Who also observed significant differences among tomato accessions for total soluble solids. Total soluble solids was significantly $(\mathrm{P} \leq 0.01)$ positive correlated with fruits plant ${ }^{-1}$, fruit weight and fruit yield plant $^{-1}$. However total soluble solids was significantly $(\mathrm{P} \leq 0.01)$ negative correlated with days to flowering while the said trait was non-significantly positive correlated with plant height (Table 4). Our studied results are in close correspondence with Golani et al. [18]. Who also found positive correlation between TSS and fruit yield. 
Table 3. Mean performance of quantative traits of tomato accessions evaluated under the agro climatic conditions of Peshawar

\begin{tabular}{|c|c|c|c|c|c|c|c|}
\hline Accession & $\begin{array}{c}\text { Fruit juice } \\
\text { PH }\end{array}$ & $\begin{array}{c}\text { Fruit } \\
\text { TSS } \\
\left({ }^{0} \text { Brix }\right)\end{array}$ & $\begin{array}{c}\text { Days to } \\
\text { flowering }\end{array}$ & $\begin{array}{l}\text { Plant height } \\
\text { (cm) }\end{array}$ & Fruits plant $^{-1}$ & $\begin{array}{c}\text { Fruit } \\
\text { weight(gm) }\end{array}$ & $\begin{array}{c}\text { Fruit yield } \\
\text { plant }^{-1}(\text { gm } \\
\left.\text { plant }^{-1}\right)\end{array}$ \\
\hline 6237 & 4.1 & $6.0 \mathrm{a}$ & $38 \mathrm{c}$ & $45.7 \mathrm{i}$ & $12.7 \mathrm{~d}$ & $5.2 \mathrm{k}$ & $70.5 \mathrm{~h}$ \\
\hline 17873 & 4.1 & $6.0 \mathrm{a}$ & $47 b$ & $43.2 \mathrm{k}$ & $20.3 b$ & $8.1 \mathrm{j}$ & $165.8 \mathrm{e}$ \\
\hline 17876 & 4.1 & $5.5 \mathrm{~b}$ & $47 \mathrm{~b}$ & $48.3 \mathrm{~h}$ & $8.1 \mathrm{~g}$ & $36.1 \mathrm{c}$ & $274.2 \mathrm{~cd}$ \\
\hline 17877 & 4.0 & $4.0 \mathrm{~d}$ & $38 \mathrm{c}$ & 30.51 & $9.5 \mathrm{f}$ & $17.1 \mathrm{f}$ & $163.1 \mathrm{e}$ \\
\hline 17882 & 4.1 & $5.5 \mathrm{~b}$ & $47 b$ & 20.30 & $8.1 \mathrm{~g}$ & $17.2 \mathrm{f}$ & $140.1 \mathrm{f}$ \\
\hline 17884 & 4.0 & $4.0 \mathrm{~d}$ & $51 \mathrm{a}$ & $101.6 \mathrm{~b}$ & $11.4 \mathrm{e}$ & $22.2 \mathrm{~d}$ & $254.9 \mathrm{~d}$ \\
\hline 19293 & 4.1 & $4.5 \mathrm{c}$ & $53 a$ & $35.56 \mathrm{k}$ & $8.1 \mathrm{~g}$ & $5.2 \mathrm{k}$ & $42.5 \mathrm{i}$ \\
\hline 19297 & 4.1 & $4.5 \mathrm{c}$ & $53 a$ & 30.51 & $9.5 \mathrm{f}$ & 4.21 & $40.3 \mathrm{i}$ \\
\hline 19843 & 4.0 & $4.0 \mathrm{~d}$ & $51 \mathrm{a}$ & $63.5 \mathrm{f}$ & $6.2 \mathrm{i}$ & $5.2 \mathrm{k}$ & $42.5 \mathrm{i}$ \\
\hline 19895 & 4.1 & $5.5 \mathrm{~b}$ & $47 \mathrm{~b}$ & 30.31 & $22.96 \mathrm{a}$ & $12.2 \mathrm{i}$ & $280.9 \mathrm{c}$ \\
\hline 19900 & 4.1 & $5.5 \mathrm{~b}$ & $38 \mathrm{c}$ & $106.7 \mathrm{a}$ & $9.5 \mathrm{f}$ & $2.2 \mathrm{n}$ & $21.2 \mathrm{i}$ \\
\hline 19903 & 4.0 & $4.0 \mathrm{~d}$ & $38 \mathrm{c}$ & $25.4 \mathrm{~m}$ & $8.1 \mathrm{~g}$ & $3.1 \mathrm{~m}$ & $24.6 \mathrm{i}$ \\
\hline 19904 & 4.1 & $4.0 \mathrm{~d}$ & $47 b$ & $76.2 \mathrm{~d}$ & $7.2 \mathrm{~h}$ & $15.2 \mathrm{~h}$ & $110.7 \mathrm{~g}$ \\
\hline 27726 & 4.1 & $5.5 \mathrm{~b}$ & $47 b$ & $55.9 \mathrm{~g}$ & $17.26 \mathrm{c}$ & $15.2 \mathrm{~h}$ & $263.1 \mathrm{~cd}$ \\
\hline 29448 & 4.1 & $5.5 \mathrm{~b}$ & $47 \mathrm{~b}$ & $22.9 n$ & $10.6 \mathrm{e}$ & $16.2 \mathrm{~g}$ & $173.14 \mathrm{e}$ \\
\hline 29471 & 3.9 & $3.5 \mathrm{e}$ & $47 \mathrm{~b}$ & $71.1 \mathrm{e}$ & $6.2 \mathrm{i}$ & $21.1 \mathrm{e}$ & $130.6 \mathrm{fg}$ \\
\hline 31910 & 4.1 & $6.0 \mathrm{a}$ & $38 \mathrm{c}$ & $86.4 \mathrm{c}$ & $13.5 \mathrm{~d}$ & $44.2 \mathrm{~b}$ & $488.2 b$ \\
\hline Roma & 4.3 & $6.1 \mathrm{a}$ & $38 \mathrm{c}$ & $101.6 \mathrm{~b}$ & $13.4 \mathrm{~d}$ & $54.2 \mathrm{a}$ & $688.7 \mathrm{a}$ \\
\hline Mean & 4.1 & 5.0 & 45 & 55.31 & 11.3 & 16.9 & 187.5 \\
\hline $\operatorname{LSD}_{(0.05)}$ & 0.41 & 0.29 & 2.57 & 0.94 & 0.63 & 0.42 & 17.31 \\
\hline
\end{tabular}

Table 4. Correlation among quantitative traits in tomato accessions evaluated under the agro climatic conditions of Peshawar

\begin{tabular}{|c|c|c|c|c|c|c|}
\hline Traits & Juice pH & $\begin{array}{c}\text { Total soluble } \\
\text { solids }\end{array}$ & $\begin{array}{c}\text { Days to } \\
\text { flowering }\end{array}$ & $\begin{array}{c}\text { Plant } \\
\text { height }\end{array}$ & $\begin{array}{c}\text { Fruits } \\
\text { plant }^{-1}\end{array}$ & $\begin{array}{c}\text { Fruit } \\
\text { weight }\end{array}$ \\
\hline Total soluble solids & $0.750^{* *}$ & & & & & \\
\hline Days to flowering & -0.200 & $-0.350^{* *}$ & & & & \\
\hline Plant height & 0.150 & 0.030 & -0.230 & & & \\
\hline Fruits plant $^{-1}$ & $0.370^{* *}$ & $0.610^{* *}$ & -0.090 & -0.060 & & \\
\hline Fruit weight $^{*}$ & $0.430^{* *}$ & $0.340^{*}$ & $-0.280^{*}$ & $0.440^{* *}$ & 0.080 & \\
\hline Fruit yield plant $^{-1}$ & $0.580^{* *}$ & $0.500^{* *}$ & $-0.310^{*}$ & $0.420^{* *}$ & $0.410^{* *}$ & $0.920^{* *}$ \\
\hline
\end{tabular}

\section{Days to flowering}

Analysis of variance revealed significant difference $(\mathrm{P} \leq 0.01)$ among tomato accessions for days to flowering (Table 5). Mean data showed that maximum days to flowering were recorded for accession 19293 (53), while minimum days to flowering were recorded for accession 31910 (38) followed by 19903 and Roma (38). Our findings are in agreement with Ullah et al. [19]. Days to flowering was significantly $(\mathrm{P} \leq 0.05)$ negative correlated with total soluble solids, fruit weight and fruit yield plant ${ }^{-1}$. Whereas days to flowering was non-significantly negative correlated with juice $\mathrm{pH}$, plant height and fruits plant ${ }^{-1}$ (Table 4).

\section{Plant height $(\mathbf{c m})$}

Statistical analysis revealed significant difference $(\mathrm{P} \leq 0.01)$ among tomato accessions for plant height. Maximum plant height was recorded for accession 19900 $(106.7 \mathrm{~cm})$ followed by Roma and 17884 $(101.6 \mathrm{~cm})$, while minimum plant height was recorded for accession $17882(20.3 \mathrm{~cm})$. Similar findings were also reported by Ambule et al. and Iqbal et al. [20, 21]. Plant height was significantly $(\mathrm{P} \leq 0.01)$ positive correlated with fruit weight and fruit yield 
plant $^{-1}$. However non-significantly positive correlated with juice $\mathrm{pH}$ and total soluble solids. Plant height was non-significant negative correlated with days to flowering and fruits plant ${ }^{-1}$ (Table 4). Izge et al. [22] also found significant positive correlation between plant height and fruit yield plant ${ }^{-1}$.

Table 5. Mean squares of quantitative traits of tomato evaluated under agro climatic condition of Peshawar

\begin{tabular}{|c|c|c|c|c|}
\hline Traits & $\begin{array}{c}\text { Replication } \\
\mathbf{d f}=\mathbf{2}\end{array}$ & $\begin{array}{c}\text { Accessions } \\
\mathbf{d f = 1 7}\end{array}$ & $\begin{array}{c}\text { Error } \\
\mathbf{d f}=\mathbf{3 4}\end{array}$ & $\begin{array}{c}\text { Coefficient of variation } \\
(\boldsymbol{\%})\end{array}$ \\
\hline Juice Ph & 0.16 & $0.02^{\mathrm{ns}}$ & 0.06 & 5.85 \\
\hline Total soluble solids & 0.02 & $2.27 * *$ & 0.03 & 3.39 \\
\hline Days to flowering & 6.22 & $83.37 * *$ & 2.22 & 3.30 \\
\hline Plant height & 1.46 & $2547.97^{* *}$ & 0.30 & 0.99 \\
\hline No of fruit plant ${ }^{-1}$ & 0.22 & $67.48^{* *}$ & 0.13 & 3.24 \\
\hline fruits weight & 0.06 & $642.05^{* *}$ & 0.06 & 1.45 \\
\hline Fruit yield plant $^{-1}$ & 169.90 & $90419.60^{* *}$ & 101.00 & 5.36 \\
\hline
\end{tabular}

ns $=$ non-significant, $\quad * *=$ significant at $1 \%$ probability level

\section{Fruits plant $\mathbf{t}^{-1}$}

Statistically analyzed data showed that there were significant difference $(\mathrm{P} \leq 0.01)$ among tomato accessions for fruits palnt ${ }^{-1}$. Greater fruits palnt ${ }^{-1}$ were recorded for accession 19895 (22.96), while less fruits palnt ${ }^{-1}$ were recorded for accession 29471 (6.2). These results are supported by the findings of Saeed et al. and Henareh et al. $[13,23]$. Fruits plant 1 was significantly $(\mathrm{P} \leq 0.01)$ positive correlated with juice $\mathrm{pH}$, total soluble solids and fruit yield plant ${ }^{-1}$. However fruits plant ${ }^{-1}$ was non-significantly positive correlated with fruit weight. Fruits per plant was nonsignificantly negative correlated with days to flowering and plant height (Table 4). Tiwari et al. [24], also reported positive correlation between fruits plant $^{-1}$ and fruit yield plant $^{-1}$ and specified that fruit yield increases with fruits plant ${ }^{-1}$.

\section{Fruit weight (gm)}

Analysis of variance revealed significant difference $(\mathrm{P} \leq 0.01)$ among tomato accessions for fruit weight. The mean data showed that maximum fruit weight was recorded for Roma (54.2 g) followed by accession 31910 (44.2g). While minimum fruit weight was noted for accession 19900 (2.2g). Similar diversity in tomato for fruit weight has been reported by Weller et al. and
Reddy and Reddy [25, 26]. Fruit weight was significantly $(\mathrm{P} \leq 0.01)$ positive correlated with juice $\mathrm{pH}$, total soluble solids, plant height and fruit yield plant ${ }^{-1}$. Similarly Fruit weight was significantly $(\mathrm{P} \leq 0.01)$ negative correlated with days to flowering and nonsignificantly positive correlated with fruits plant $^{-1}$ (Table 4). Our findings are in correspondence with Golani et al. [18], who also found that fruit weight was significantly positive correlated with fruit yield.

\section{Fruit yield plant $^{-1}\left(\right.$ gm plant $\left.^{-1}\right)$}

Statistical analysis of the data showed significant difference $(\mathrm{P} \leq 0.01)$ among tomato accessions for fruit yield plant ${ }^{-1}$. The mean comparison showed that maximum fruit yield plant $^{-1}$ was obtained from Roma (688.70) followed by accession 31910 $(488.20 \mathrm{~g})$. While the minimum fruit yield plant $^{-1}$ were obtained from accession 19900 $(21.2 \mathrm{~g})$. Our results are in agreement with the findings of Mukul et al. and Mohanty [27, 28]. Fruit yield plant $^{-1}$ was significantly $(\mathrm{P} \leq$ 0.01 ) positive correlated with juice $\mathrm{pH}$, total soluble solids, plant height, fruits plant ${ }^{-1}$ and fruit weight. However fruit yield plant ${ }^{-1}$ was significantly $(\mathrm{P} \leq 0.05)$ negative correlated with days to flowering (Table 4). Kumar et al. and Denton et al. [29, 30] also reported positive phenotypic correlation of fruit yield 
plant $^{-1}$ with TSS, plant height, fruits plant ${ }^{-1}$ and fruit weight.

Descriptive statistics of qualitative traits of tomato accessions

Qualitative traits viz plant growth type, canopy size, leaf type, flowers inflorescence

1 and inflorescence types were recorded following IPGRI descriptor list for tomato and there results are presented in (Table 6). Frequency distribution of plant growth type showed that out of 18 tomato genotypes 16 were indeterminate with a percentage of 88.9, while two were determinate with a percentage of $11.1 \%$. Canopy size showed that a total of 18 genotypes five have large canopy size with a percentage of $27.8 \%$. On other hand 10 genotypes with $55.8 \%$ were intermediate and three genotypes with $16.7 \%$ have small canopy size. Leaf type showed that 12 genotypes with $66.7 \%$ exhibited curled leaf type while, 6 genotypes with $33.3 \%$ revealed regular leaf type. Flowers per inflorescence showed that out of 18 genotypes 10 with a percentage of $55.6 \%$ were noted medium, followed by high with 5 genotypes with percentage of $27.8 \%$ and three were observed low with percentage of $(16.7 \%)$. Type of inflorescence revealed that out of 18 genotypes 17 showed simple inflorance with percentage of $94.4 \%$ while one genotype showed compound inflorescence with percentage of $5.6 \%$. Fruit character of qualitative nature with individual classes like exterior color of mature fruit, fruit shape and fruit firmness results are presented in (Table 7). Frequency distribution of fruit color showed the predominance of red color for five genotypes with $27.8 \%$, followed by orange in 11 genotypes $(61.1 \%)$, pink in one genotype $(5.6 \%)$ and gold in one genotype (5.6\%). Fruit shape of four genotypes $(22.2 \%)$ was found to be flattened, two genotypes $(11.1 \%)$ were slightly flattened, three genotypes (16.7\%) were globe, five genotypes $(27.8 \%)$ were deep globe, only one genotype $(5.6 \%)$ were heart shaped, one were cylindrical $(5.6 \%)$ and two genotypes $(11.1 \%)$ were Pyriform. Fruit firmness of 15 genotypes $(83.3 \%)$ have soft fruit and 3 genotypes $(16.7 \%)$ had medium fruits firmness. Similar findings were also observed earlier by Grandillo et al. [31]. They also reported significant variation among tomato accessions for qualitative traits.

Table 6. Frequency distribution of qualitative morphological characters of tomato germplasm tested under agro climatic condition of Peshawar

\begin{tabular}{|c|c|c|}
\hline Plant characteristics & Frequency & Percent \\
\hline \multicolumn{3}{|c|}{ Plant growth type } \\
\hline Dwarf & 0 & 0.00 \\
\hline Determinate & 2 & 11.1 \\
\hline Semi-determinate & 0 & 0.00 \\
\hline Indeterminate & 16 & 88.9 \\
\hline \multicolumn{3}{|c|}{ Canopy size } \\
\hline Small & 3 & 16.7 \\
\hline Indeterminate & 10 & 55.6 \\
\hline Large & 5 & 27.8 \\
\hline \multicolumn{3}{|c|}{ Leaf type } \\
\hline Rugose & 0 & 0.00 \\
\hline Potato leaf & 0 & 0.00 \\
\hline Regular & 6 & 33.3 \\
\hline Curled & 12 & 66.7 \\
\hline \multicolumn{3}{|c|}{ Flowers inflorence $^{-1}$} \\
\hline Low & 3 & 16.7 \\
\hline Medium & 10 & 55.6 \\
\hline
\end{tabular}




\begin{tabular}{|c|c|c|}
\hline High & 5 & 27.8 \\
\hline \multicolumn{1}{|c|}{ Type of inflorescence } \\
\hline Simple & 17 & 94.4 \\
\hline Forked & 0 & 0.00 \\
\hline Compound & 1 & 5.6 \\
\hline
\end{tabular}

Table 7. Fruit characters of tomato germplasm tested under agro climatic condition of Peshawar

\begin{tabular}{|c|c|c|}
\hline Fruit characteristics & Frequency & Percent \\
\hline \multicolumn{2}{|c|}{ Fruit color } \\
\hline white & 0 & 0.00 \\
\hline Green & 0 & 0.00 \\
\hline Yellow & 0 & 0.00 \\
\hline Gold & 1 & 5.6 \\
\hline Orange & 11 & 27.8 \\
\hline Pink & 1 & 5.6 \\
\hline Red & 5 & 61.1 \\
\hline Oblate & 4 & 22.2 \\
\hline Deep oblate & 2 & 11.1 \\
\hline Globe & 3 & 16.7 \\
\hline Deep globe & 5 & 27.8 \\
\hline Heart shaped & 1 & 5.6 \\
\hline Cylindrical & 1 & 5.6 \\
\hline Pyriform & 2 & 11.1 \\
\hline Soft & 15 & 83.3 \\
\hline Medium & 3 & 16.7 \\
\hline Hard & 0 & 0.00 \\
\hline
\end{tabular}

\section{Conclusions}

Analysis of variance showed significant difference among the tomato accession for all the studied traits except juice $\mathrm{pH}$ which showed non-significant differences among tomato accessions. Maximum fruit yield plant $^{-1}$ was recorded for Roma (688.70) followed by accession $31910(488.20 \mathrm{~g})$. While minimum fruit yield plant ${ }^{-1}$ was noted for accession 19900 (21.2 g). Qualitative results revealed that maximum accessions have indeterminate growth habit, Intermediate canopy size, curled leaf type, medium number of flowers inflorescence ${ }^{-1}$, red fruit color, deep globe fruits and soft fruit firmness. Fruit yield plant ${ }^{-1}$ showed significant positive correlation with juice $\mathrm{pH}$ $\left(\mathrm{r}=0.580^{* *}\right)$, TSS $\left(\mathrm{r}=0.500^{* *}\right)$, plant height $\left(\mathrm{r}=0.420^{* *}\right)$, fruits plant ${ }^{-1}\left(\mathrm{r}=0.410^{* *}\right)$ and fruit weight $(\mathrm{r}=0.920 * *)$ except days to flowering $\left(\mathrm{r}=-0.310^{* *}\right)$ which showed significant negative correlation with fruit yield plant ${ }^{-1}$. Roma performed better followed by accession (31910). Therefor it is suggested that these two tomato genotypes could be used in future tomato breeding programs.

\section{Authors' contributions}

Conceived and designed the experiments: $\mathrm{N}$ Ara, Performed the experiments: N Samad, Analyzed the data: S Ali, Contributed reagents/materials/ analysis tools: Manzoor, S Fahad and Q Hussain, Wrote the paper: A Sohail.

\section{References}

1. Foolad MR (2007). Genome mapping and molecular breeding of tomato. Int. J. Plant Genomics. 6(1): 43-58.

2. Weese TL and Bohs L (2007). A threegene phylogeny of the genus Solanum. Sys Bot 32(2): 445-463. 
3. Peralta IES, Knapp DM, Spooner DM and Knapp (2008). Taxonomy of wild tomatoes and their relatives: Solanum sect. Lycopersicoides, sect. Juglandifolia, sect. Lycopersicon; Solanaceae. 3(2): 56-66.

4. Norman JC (1992). Tropical vegetable production. Macmillan. Press Ltd. UK. Pp 52-67.

5. Pakistan Agriculture Statistics of Pakistan, Ministry of food (2014-15), Agriculture and Livestock Islamabad.

6. Dar RA, Sharma JP and Ahmad M (2015). Genetic diversity among some productive genotypes of tomato (Lycopersicon esculentum Mill.). African J of biotech 14(22): 1846-1853.

7. Nkansah GO, Owusu O, Bonsu KO, and Dennis EA (2003). The effect of mulch types on growth, yield and fruit quality of tomato (Lycopersicon esculentum Mill).Ghana J Hort 2: 55-63.

8. Fraser D, Truesdale MR, Bird CR, Schuch W and Bramley M (1994). Carotenoid biosynthesis during tomato fruit development. Plant Physiology 105: 405-413.

9. Agong SG, Schittenhelm S and Fried W (2001). Genotypic variation of Kenyan tomato germplasm. J Food Tech Africa 6(1): 13-17.

10. IPGRI [International Plant Genetic Resources Institute] (1996). Descriptors for tomato. IPGRI, Rome, Italy.

11. Steel RGD and Torrie JH (1960). Principles and procedures of statistics, a biological approach, 2nd edition. McGraw Hill, Inc. New York, Toronto, London.

12. Ghasemi S, Ghasemi M, Abbaszadeh K and Salari M (2015). Evaluation of some quantitative and qualitative characteristics of 5 cultivars of tomato (Lycopersicum esculentum) grown in Hormozgan Province. Inter J of Agro \& Agric Res 6(5): 62-65.
13. Henareh M, Dursun A and Mandoulakani BA (2015). Genetic diversity in tomato landraces collected from turkey and iran revealed by morphological characters. Acta Sci Pol Hortorum Cultus 14(2): 87-96.

14. Olakojo SA and Adetula OA (2014). Comparison of qualitative and quantative traits of some advanced breeding lines of tomato (Solanum lycopersicum L.). African J Pl Sci 8(10): 457-461.

15. Aoun AB, Lechiheb B, Benyahya L and Ferchichi A (2013). Evaluation of fruit quality traits of traditional varieties of tomato (Solanum lycopersicum) grown in Tunisia. African Jfood Sci 7(10): 350354.

16. Chernet S, Belew D and Abay F (2014). Genetic diversity studies for quantitative traits of tomato (Solanum lycopersicum L.) genotypes in Western Tigray, Northern Ethiopia. J Pl breed \& crop Sci 6(9): 105-113.

17. Parker R, Maalekuu BK (2013). The effect of hervesting stage on fruit quality and shelf-life of four tomato cultivars (Lycopersicon esculentum mill). Agric and Biol J of North America.

18. Golani IJ, Mehta DR, Purohit VL, Pandya HM and Kanzariya MV (2007). Genetic variability, correlation and path coefficient studies in tomato. Indian $J$ Agric Res 41(2): 146-149.

19. Ullah MZ Hassan L Shahid SB and Patwary AK (2015). Variability and inter relationship studies in tomato (Solanum lycopersicum L.). J Bangladesh Agric Univ 13(1): 65-69.

20. Ambule AT, Radadia GG, Patiland DL and Toke NR (2015). Morphological Characters of Tomato in Relation to Resistance against Tomato Fruit Borer, Helicoverpa armigera (Hubner). Int $J$ Plant Prot 8(1): 152-156. 
21. Iqbal Q, Saleem MY, Hameed A and Asghar M (2014). Assessment of genetic divergence in tomato through Agglomerative hierarchical clustering and Principal component analysis. Pak J Bot 46(5): 1865-1870.

22. Izge AU and Garba Y (2014). Correlation and Path Coefficients in Tomato (Solanum lycopersicon Mill) under Fruit Worm (Helicoverpa zea Buddie) Infestation in Line $\times$ Tester Breeding. Czech University of Life Sciences, Prague. 17-19 September.

23. Saeed A, Hayat K, khan AA, Iqbal S and Abbas G (2007). Assessment of genetic variability and heritability in Lycopersicon esculentum mill. Inter $J$ Agric \& Biol 9(2): 375-377.

24. Tiwari JK and Upadhyay D (2011). Correlation and Path-coefficient Studies in Tomato (Lycopersicon esculentum Mill.). Res J of Agric Sci 2(1): 63-68.

25. Weller JI, Soller M and Brody T (1988). Linkage analysis of quantitative traits in tomato. Annual reviewers 5: 131-160.

26. Reddy WVP and Reddy KV (1992). Studies on variability in tomato. South Indian Hort. 40: 257-260.
27. Mukul K, Srivastava, Vishal K. Agrawal and Agrawal RK (2014). Estimation of genetic divergence among indigenous an exotic accessions of tomato (Solanum lycopersicum L.). Asian J Bio Sci 9(1): 30-34.

28. Mohanty MK (2003). Genetic variability, correlation and path coefficient studies in tomato. Indian $J$ Agric Sci 37: 68-71.

29. Kumar V, Nandan R, Srivastava K, Sharma SK, Kumar R and Kumar A (2013). Genetic parameters and correlation study for yield and quality traits in tomato (solanum lycopersicum 1.). Plant Archives 13(1):463-467.

30. Denton OA and Nwangburuka CC (2011). Heritability, Genetic Advance and Character Association in six yield Related Characters of Solanum anguivi. Asian J of Agric. Res 10(1): 23-29.

31. Grandillo $\mathrm{S}, \mathrm{Ku} \mathrm{HM}$ and Tanksley SD (1999). Identifying the loci responsible for natural variation in fruit and shape in tomato. Theor Appl Genet 99: 978-987. 